\title{
Overcoming Exclusion and Marginalization in Education through Inclusive Approaches: Challenges and Vision of Arunachal Pradesh in India
}

\author{
Soubhagya Ranjan Padhi
}

\begin{abstract}
After independence, Indian national leaders have taken special care for formulating some special provisions of education to enhance the socio-economic status of backward sections and envisage all round development of the most deprived social sections known as aboriginal or Scheduled Tribes. In spite of all the loud rhetoric on the empowerment of STs, the conditions of this community have not improved to the extent desirable since independence. The disparity in education in particular is widening over the years. Effective machinery should be created to review all hitherto existing educational policies to plug loopholes, strict enforcement of the provision for education and to reduce the inequality in education. Against this backdrop, this paper has tried to critically analyze the educational status of tribal communities in Arunachal Pradesh and explore the constraints in enhancing the educational levels of this marginalized section. It is in this context that this paper seeks to map out inclusive approaches in education as a strategy to achieve the goal of education for all. It aims to construct a coherent conceptual and contextual policy framework in order to provide access and quality in basic education for all children and young people, and what it implies for education systems so that these needs can be addressed and responded to in mainstream of education whether it is formal or non-formal.
\end{abstract}

Index Terms-Education, exclusion, inclusion and marginalization.

\section{INTRODUCTION}

One of the greatest problems facing the world today is the growing number of persons who are excluded from meaningful participation in the economic, social, political, cultural and educational life of their communities. It is recognized that current strategies and programmes have largely been insufficient or inappropriate with regard to needs of children and youth who are vulnerable to marginalization and exclusion. Where programmes targeting various marginalized and excluded groups do exist, they have functioned outside the mainstream - special programmes, specialized institutions, and specialist educators. Notwithstanding the best intentions, too often the result has been exclusion: 'second-rate' educational opportunities that do not guarantee the possibility to continue studies, and differentiation becoming a form of discrimination, leaving children with various needs outside the mainstream of school life and later, as adults, outside community social and cultural life in general [1].

The urgency to address the needs of learners who are

Manuscript received August 19, 2014; revised December 16, 2014.

Soubhagya Ranjan Padhi is with the Rajiv Gandhi Central University, India (e-mail: srustisilpi@gmail.com). vulnerable to marginalization and exclusion was also pointed out in the Dakar World Education Forum:

"The key challenge is to ensure that the broad vision of Education for All as an inclusive concept is reflected in national government and funding agency policies. Education for All ... must take account of the need of the poor and the most disadvantaged, including working children, remote rural dwellers and nomads, and ethnic and linguistic minorities, children, young people and adults affected by conflict, HIV/AIDS, hunger and poor health; and those with special learning needs..." [2].

The present millennium is witnessing phenomenal global changes and no nation can isolate itself from this process. The desirability of globalization have now given way to the growing reorganization that this process is not just reversible but also probably unstoppable. Its pace is fast accelerating with a continuous free flow of information, investment capital, human capital, opportunities, goods and services between countries. Parallel to emergence and spread of globalization there has occurred fast transformation of societies into 'Knowledge societies'. Acknowledging this, $21^{\text {st }}$ century has been described as 'Knowledge Century Era' in which knowledge will be the resource and knowledge workers will be the dominant force. In the process of global changes and development our country has achieved success in various fields like industrialization, urbanization, modernization, communication, science, technology etc. With the result of these phenomenal changes education are also expanding at every corner in India. After independence, the country has become more conscious to educate our backward communities. Therefore various educational schemes and programmes have been introduced to attain higher level of education and to enhance awareness for achieving socio-economic development. Nevertheless, this educational expansion has not taken place equally for every section of society.

In recent years, one of the most frequently discussed topics in the social sciences has been the deprivation of socially excluded groups and communities. The issues of social discrimination, exclusion, illiteracy, human rights and poverty alleviation have gained priorities in academic discussions and discourses. The understanding of these issues and their linkages to the social, human, institutional and economic dimensions involved in the process of social development, are important for effective policy paradigms. The concept of 'social exclusion' gained currency in the eighties, seems to cover remarkably wide range of social, economic, political and cultural problems. René Lenoir, 
Secretary of Social Action of the then French Government, to whom the authorship of the term is attributed to, defines social exclusion as a 'rupture of social bonds'. More broadly, social exclusion has been defined as the process through which individuals or groups are wholly or partially excluded from full participation in the society within which they live. Social exclusion is defined as the opposite of social integration, mirroring the perceive importance of being part of society, of being 'included'.

The Scheduled Tribes, one of the major segments of marginalized section of Indian society are still lagging behind in all stages of education and completely excluded from the mainstream society. Despite constant efforts by both central and state governments to spread the education of Scheduled Tribes, the level of education of STs is very low in comparison to general castes and other communities. Therefore the most urgent priority is to ensure access to, and improve the quality of education for tribals to remove every obstacle that hampers their active participation in developmental processes.

\section{INCLUSION - A DEVELOPMENTAL APPROACH IN EDUCATION}

Inclusive education as an approach seeks to address the learning needs of all children, youth and adults with a specific focus on those who are vulnerable to marginalization and exclusion. The principle of inclusive education was adopted at the Salamanca World Conference on Special Needs Education, UNESCO, 1994. Inclusive education means that "... Schools should accommodate all children regardless of their physical, intellectual, social, emotional, linguistic or other conditions. This should include disabled and gifted children, street and working children, children from remote or nomadic populations, children from linguistic, ethnic or cultural minorities and children from other disadvantaged or marginalized areas or groups" [3].

Inclusion is seen as a process of addressing and responding to the diversity of needs of all learners through increasing participation in learning, cultures and communities, and reducing exclusion within and from education. It involves changes and modifications in content, approaches, structures and strategies, with a common vision which covers all children of the appropriate age range and a conviction that it is the responsibility of the regular system to educate all children.

Inclusive education is concerned with providing appropriate responses to the broad spectrum of learning needs in formal and non-formal educational settings. Rather than being a marginal theme on how some learners can be integrated in the mainstream education, inclusive education is an approach that looks into how to transform education systems in order to respond to the diversity of learners. It aims to enable both teachers and learners to feel comfortable with diversity and to see it as a challenge and enrichment in the learning environment, rather than a problem.

Education has been considered as a critical input for economic and social development. It empowers disadvantaged groups with increased efficiency and ability to protect their interest, raise voice against oppression and make them politically conscious. Literacy is the first step of empowerment of an individual; it opens the door to acquire knowledge. It is the pre-requisite factor, which improves human capabilities, enhance increased participation of people in production and thus, establish synergic relationship between human development and social development. In recent days "inclusion" is the progress mantra for policy makers of our country. In this context of inclusive growth, "education" is the best input that can open up opportunity, empower marginalized section, ignite social change and catalyze economic growth [4]. The Eleventh Plan's strategy on education is directed towards achieving inclusive growth. This strategy envisages bridging regional, social and gender gaps at all levels of education by eliciting a participatory development process [5].

\section{THE INSTANCE OF MARGINALIZATION OF EDUCATION IN ARUNACHAL PRADESH}

In Arunachal Pradesh, the formal system of education started with the opening of schools and establishment of the office of the Education Officer in 1947. No doubt it has made progress in the field of formal education after independence. But in spite of all the schemes and efforts, about more than two-fifths of the population are still illiterate. Besides, free and compulsory elementary education to all the children in the age group of 6-14, the literacy rate in the state is not so high $(66.95 \%)$ as compared to that of Kerala (93.91\%), Goa $(87.40 \%)$ and some of the north-eastern states like Mizoram $(91.58 \%)$, Tripura $(87.75 \%$ and Sikkim $(82.20 \%)$. Arunachal Pradesh is placed among the three bottom ranked states of India in terms of literacy rate [6]. This implies that along with adult illiterates there are non-school going children adding to the number of illiterates. In addition to the above problem, access of to higher and technical education is also miserable. All these things speak about marginalization of education in Arunachal Pradesh.

Table I shows the gap between Arunachal and All India Level in terms of literacy. No doubt the literacy rate has increased from 7.23 percent in 1961 to 66.95 percent in 2011, but in comparison to the National average the literacy rate of Arunachal Pradesh is still less. The literacy gap between Arunachal Pradesh and the Nation is also evident in terms of both male literacy and female literacy.

TABLE I: A COMPARISON BETWEEN LITERACY OF ARUNACHAL PRADESH

\begin{tabular}{|l|c|l|l|l|l|l|l|}
\hline $\begin{array}{l}\text { S1 } \\
\text { No. }\end{array}$ & Year & \multicolumn{2}{|c|}{$\begin{array}{l}\text { Arunachal Pradesh } \\
\text { (in percentage) }\end{array}$} & \multicolumn{3}{|c|}{$\begin{array}{l}\text { All India level } \\
\text { (in percentage) }\end{array}$} \\
\hline & & Male & Female & Person & Male & Female & Person \\
\hline 01 & 1951 & --- & --- & --- & 27.16 & 8.86 & 18.33 \\
\hline 02 & 1961 & 12.24 & 1.42 & 7.23 & 40.33 & 15.35 & 28.30 \\
\hline 03 & 1971 & 17.82 & 3.71 & 11.29 & 45.96 & 21.95 & 34.45 \\
\hline 04 & 1981 & 35.11 & 14.01 & 25.54 & 56.38 & 29.76 & 43.53 \\
\hline 05 & 1991 & 51.45 & 29.69 & 41.59 & 64.13 & 39.29 & 52.21 \\
\hline 06 & 2001 & 64.07 & 44.24 & 54.74 & 75.38 & 54.16 & 65.38 \\
\hline 07 & 2011 & 73.69 & 59.57 & 66.95 & 82.14 & 65.46 & 74.04 \\
\hline
\end{tabular}

Source: Census report, 1961, 1971, 1981, 2001 and 2011 
Table II indicates that Arunachal has the low literacy rate among all the north-east states. In 1991census Mizoram had the highest literacy rate i.e. 82.27 percent but Arunachal had the lowest literacy rate of only 41.59 percent. Likewise in 2011 also Arunachal had the lowest literacy rate among all the north east states i.e. 66.95 percent in comparison to the highest literacy rate achieved by Mizoram i.e. 91.58 percent. This gap, certainly speaks about the marginalization of education in Arunachal Pradesh.

TABLE I: LITERACY RATE OF NORTH- EASTERN STATES (2001- 2011)

\begin{tabular}{|l|l|l|l|l|l|l|}
\hline State & \multicolumn{3}{l|}{ Literacy Rate(2001) } & \multicolumn{3}{l|}{ Literacy Rate(2011) } \\
\hline & Male & Female & Total & Male & Female & Total \\
\hline Arunachal Pradesh & 63.83 & 43.53 & 54.34 & 73.69 & 59.57 & 66.95 \\
\hline Assam & 71.28 & 54.61 & 65.25 & 78.81 & 67.27 & 73.18 \\
\hline Manipur & 80.33 & 60.53 & 70.53 & 86.49 & 73.17 & 79.85 \\
\hline Meghalaya & 65.43 & 59.61 & 62.56 & 77.17 & 73.78 & 75.48 \\
\hline Mizoram & 90.72 & 86.75 & 88.80 & 93.72 & 89.40 & 91.58 \\
\hline Nagaland & 71.16 & 61.46 & 66.59 & 83.29 & 76.69 & 80.11 \\
\hline Sikkim & 76.04 & 60.40 & 68.81 & 87.29 & 76.43 & 82.20 \\
\hline Tripura & 81.02 & 64.91 & 73.19 & 92.18 & 83.15 & 87.75 \\
\hline
\end{tabular}

Source: census of India 2001, census of 2011

The total population of Arunachal Pradesh in 2001 Census has been $1,097,968$. Of these 705,158 persons are Scheduled Tribes (STs), constituting 64.2 per cent of the total population. The STs in Arunachal Pradesh are predominantly living in rural areas (86 per cent). Among STs, 49.6 percent of the population has been returned as literate. As many as thirteen STs have overall literacy level below 50 per cent and for Wancho tribe it is low at 25.4 percent. While male literacy is at 58.8 percent, female literacy is only 40.6 percent. The female literacy is depressed as seventeen STs have recorded literacy below 50 percent. In every tribe female literacy is low in comparison to their male counterpart.

TABLE III: LITERACY RATE AMONG SELECTED STS

\begin{tabular}{|c|c|c|c|c|}
\hline \multirow[t]{2}{*}{ SL No } & \multirow[t]{2}{*}{ Name of the Scheduled Tribe } & \multicolumn{3}{|c|}{ Literacy Rate ( 7 years and above) } \\
\hline & & Total & Male & Female \\
\hline 1 & All Scheduled Tribes & 49.6 & 58.8 & 40.6 \\
\hline 2 & Abor & 57.0 & 66.2 & 48.3 \\
\hline 3 & Adi & 58.9 & 66.3 & 51.5 \\
\hline 4 & Adi Gallong & 60.7 & 66.8 & 54.6 \\
\hline 5 & Adi Minyong & 56.8 & 63.1 & 50.5 \\
\hline 6 & Adi Padam & 63.3 & 71.0 & 55.7 \\
\hline 7 & Aka & 48.0 & 58.1 & 38.6 \\
\hline 8 & Any Naga Trbes & 46.9 & 57.0 & 35.2 \\
\hline 9 & Apatani & 70.6 & 78.4 & 63.2 \\
\hline 10 & Bangni & 41.0 & 54.4 & 27.5 \\
\hline 11 & Dafla & 37.6 & 48.4 & 27.5 \\
\hline 12 & Deori & 76.9 & 84.8 & 68.7 \\
\hline 13 & Galong & 63.1 & 69.2 & 57.2 \\
\hline 14 & Idu/Chulikata Mishmi & 55.2 & 65.7 & 45.0 \\
\hline 15 & Khampti & 72.8 & 81.2 & 63.9 \\
\hline 16 & Miji & 38.8 & 47.6 & 29.5 \\
\hline 17 & Mishing/Miri & 53.4 & 66.7 & 39.5 \\
\hline 18 & Mishmi & 39.6 & 51.4 & 27.9 \\
\hline 19 & Monpa & 42.6 & 51.0 & 34.5 \\
\hline 20 & Nishang & 37.3 & 46.2 & 28.7 \\
\hline 21 & Nissi & 46.2 & 55.7 & 36.8 \\
\hline 22 & Nocte & 47.2 & 60.0 & 34.6 \\
\hline 23 & Tagin & 47.4 & 57.2 & 37.8 \\
\hline 24 & Tangsa & 55.6 & 66.3 & 44.8 \\
\hline 25 & Tawang Monpa & 32.3 & 41.8 & 23.8 \\
\hline 26 & Wancho & 25.4 & 35.9 & 14.6 \\
\hline
\end{tabular}

Again among ST literates, only 3.5 per cent are having educational level of graduation and above. The Abor, Adi, Apatani, and Adi Padam have recorded more than 5 per cent of their literates having this status. On the other hand, Wancho, Aka, Bangni, Miji, and Nocte are quite lagging behind in higher education having the percentage of the total literates having educational level graduation and above of just around one per cent. This data certainly shows about the marginalization the tribal people face in their society. Another point of exclusion can be observed that women of all tribes are lagging behind tribal men in terms of literacy rate.

Poverty, ethnicity, region, disability, gender or membership of a minority group may limit access to or marginalize within education. The constraint in universalization of education has two dimensions. One is relating to the non-school going children and the other relating to school going but non-completing students i.e. drop outs. The former could be explained in terms of poverty, lack of school facilities within the reach of children and indifferent attitudes of parents towards children education. The latter, on the other hand, has deeper implications [7].

Poverty, unemployment ignorance of children etc. are some of the common factors which deny many children accessing to available educational facilities. Even there are schools; children do not go for study due to one or all the reason enumerated above. Besides, there are villages which do not have schools at all. In Arunachal Pradesh there are 4200 habitations but only 1,337 primary schools. 2,535 habitations do not serve for primary stage and 52 villages do not have primary schooling facilities at all. This lack of infrastructure, deny children of these villages access to primary education.

Wastage and stagnation are the main causes of marginalization of education. Wastage is an indicator which shows non-completion of a level of education by a section of students who were admitted to that level. Wastage is the premature withdrawal of children from school at any stage before the completion of the primary courses. In Arunachal Pradesh the incidence of wastage or drop-outs is higher at upper primary stage, i.e. at class-VI.

Stagnation, on the other hand, is the retention of a child in lower classes for a period of more than one year. Stagnation to a greater degree, leads to wastage. Due to the stagnation, the parents withdraw the pupils or the pupils themselves discontinue studies. It is because of illiteracy and ignorance of the parents that a child does not get guidance at home so gets stagnant which eventually leads to wastage. There are also inbuilt weaknesses in the educational system which does not make education attractive to the children. It is observed that the lack of proper articulation between education and life and the poor facility at school do not attract and hold students. With poor infrastructure, insufficient teachers accelerate drop-outs. It is surprising to note that there are 35 primary schools in rural areas without building and 355 with kaccha building.

In Arunachal Pradesh the drop-out rate at primary stage for the year 2004-05 has been recorded at 46.85; the girls, registering a little higher percentage $(48.01 \%)$ than boys $(45.86 \%)$. At elementary stage this is recorded at $62.63 \%$; the boys registering higher percentage $(63.22 \%)$ than girls 


\section{$(61.90 \%)$.}

Comparative study of CBSE results of class-X and class -XII of the student of Arunachal Pradesh in Government and private schools also describe the marginalization and exclusion of economically poor students. Those, who are rich, usually send their children to private school can afford for extra tuition and therefore do better result. On the other hand the economically poor student cannot send their children to private school because the school fee is quite high and cannot provide the proper study materials to their children. As a result of this their children joined in government school and get less success.

TABLE IV: COMPARATIVE STUdy OF CBSE RESUltS OF Class-X AND ClASS - XII OF THE STUDENT OF ARUNACHAL PRADESH IN GOVERNMENT AND PRIVATE Schools ( SOURCE: DiRECTORATE OF SCHOOl EducATION, GOVERNMENT OF ARUNACHAL PRADESH, ITANAGAR)

\begin{tabular}{|l|l|l|l|l|l|}
\hline \multicolumn{5}{|c|}{ Class - X } \\
\hline Year & No of students appeared & No of students passed & Pass\% \\
\hline \multirow{2}{*}{ 2002-03 } & Government & 9384 & Government & 1973 & 21.02 \\
& Private & 1454 & Private & 1023 & 70.49 \\
\hline \multirow{2}{*}{$2003-04$} & Government & 9965 & Government & 2275 & 22.82 \\
& Private & 1455 & Private & 1100 & 75.60 \\
\hline \multirow{2}{*}{$2004-05$} & Government & 10728 & Government & 2117 & 19.73 \\
& Private & 1669 & Private & 1226 & 73.45 \\
\hline \multirow{5}{*}{ Year } & No of students appeared & No of students passed & Pass\% \\
\hline \multirow{2}{*}{$2002-03$} & Government & 5803 & Government & 2367 & 40.78 \\
& Private & 607 & Private & 431 & 71.00 \\
\hline \multirow{2}{*}{$2003-04$} & Government & 6755 & Government & 2869 & 42.47 \\
& Private & 618 & Private & 445 & 72.00 \\
\hline \multirow{2}{*}{$2004-05$} & Government & 7222 & Government & 2884 & 39.93 \\
& Private & 575 & Private & 504 & 87.65 \\
\hline
\end{tabular}

Table IV shows that in comparison to private school students, the performance of Government school student is low. This also exposes the exclusion of poor and rural students in Arunachal Pradesh.

\section{FACTORS CAUSE EXCLUSION}

Inequalities in a society, lack of access to basic services and poverty are factors which place children at risk; contribute to learning breakdown and exclusion. Inequalities resulting from apartheid and economic deprivation have had a great impact on the education system, and especially on those learners who face barriers to learning. Some of the major causes of exclusion have been discussed below.

\section{A. Problems in the Provision and Organization of Education}

There is not an accurate picture of the number of learners excluded from the school system. These learners include those who have never attended school and those who have dropped out.

Only a small percentage of learners who were earlier categorized as having 'special needs' receive appropriate education in ordinary schools or special settings.

There is not support available for those learners who are outside the system.
Existing provision after primary school is inadequate to meet the needs. The provision and the distribution of resources reflect the inequalities of the apartheid past.

Learners who have historically faced barriers to learning have had few opportunities for further education at the tertiary level.

\section{B. Socio-Economic Factors Which Place Learners at Risk}

Inadequacies and inequalities in the education system and its contribution to learning breakdown are most evident in areas which have the lowest level of basic service provision, the highest levels of unemployment and sustained poverty.

Violence and abuse in society have impacted significant numbers of learners.

HIV/AID continues to place large numbers of learners at risk.

\section{Curriculum}

The curriculum has been unable to meet the needs of a wide range of different learners. In addition to problems in access, factors such as poor quality of the teaching, irrelevant curriculum may lead to marginalization and exclusion.

\section{Environment}

The vast majority of centers of learning are physically inaccessible to many learners, especially to those who have physical disabilities. In poorer, particularly rural areas, the centers of learning are often inaccessible largely because in education buildings are rundown or poorly maintained. They are unhealthy and unsafe for all learners.

\section{E. Language and Communication}

Teaching and learning takes place through a language which is not the first language of many learners. This places these learners at a disadvantage and it often leads to significant linguistic difficulties which contribute to learning breakdown. Second language learners are particularly subject to low expectations, discrimination and lack of role models and cultural peers.

\section{F. Inadequate and Fragmented Human Resource Development}

The training needs of staff at all levels are not being adequately met. Little or no training and capacity building opportunities exist for community resource persons, particularly careers. Training tends to be fragmented, uncoordinated, inadequate, unequal and often inappropriate to the needs of a community.

\section{OVERCOMING EXCLUSION THROUGH INCLUSIVE APPROACHES IN EDUCATION}

\section{A. Maintaining Quality}

In our country, the major constraint is the serious shortage of resources - lack of schools or inadequate facilities, lack of teachers and/or shortage of qualified staff, lack of learning materials and absence of support. There is also a serious concern about the quality of education. Although our country has made recommendable progress towards achieving the goal of Education for All, this has come 
through sacrificing the quality.

\section{B. Removal of Inappropriate Policies}

In some countries there may still exist policies that give a possibility for authorities to declare that some children are 'uneducable'. Usually this practice applies to children with severe intellectual disability. These children might be taken care of but not necessarily provided with educational opportunities. These kinds of policies should be removed to reduce exclusion in education system.

\section{Funding}

If funds are not allocated in line with an explicit inclusion policy, inclusion is unlikely to happen in practice. The government must provide attractive funding in support of inclusive education with a strongly decentralized system where budgets for supporting learners with 'special needs' are delegated to local institutions (municipalities, districts, school clusters), and funds are based on total enrolment and other such indicators.

\section{Reduction of Dropout Rates}

Empowerment and regular involvement of village educational committee such as Mother Teachers Association (M.T.A) and Parent Teachers Association (P.T.A) are necessary for persuading the parents to send the children to school. The livelihood problems of tribal people must immediately addressed through various government programmes. Education Guarantee Scheme (EGS) should be reintroduced to facilitate the children of small hamlet for education. Residential schools must be introduced in every village panchayats. ICDS centers in every village should properly work to facilitate pre-school learning. The school should have the proper infrastructure like boundary, lavatory, playground, drinking water facility which will attract the students for education. Awareness campaigning for the parents is vital to reduce the dropout rate in tribal areas. Besides this midday meal and health check-up should continue on regular basis. Timely supply of text books, learning materials and school uniforms is also very necessary to reduce the dropout rate in tribal areas.

\section{E. Curriculum-Challenges and Possibilities for Inclusion}

In any education system, the curriculum is one of the major obstacles or tools to facilitate the development of more inclusive system.

In many contexts, the curriculum is extensive and demanding, or centrally designed and rigid, leaving little flexibility for local adaptations or for teachers to experiment and try out new approaches. The content is distant to the reality in which the students live, and therefore inaccessible and unmotivating. The curriculum is also gender biased and degrading.

The paper suggests some key elements for curricula that aim at developing more inclusive education:

1) Broad common goals defined for all, including the knowledge, skills and values to be acquired.

2) A flexible structure to facilitate responding to the diversity and providing diverse opportunities for practice and performance in terms of content, methods and level of participation.

3) Cultural, religious and linguistic diversity of learners acknowledged and.

4) Content, knowledge and skills relevant to learners' context.

The curriculum can facilitate the development of more inclusive settings when it leaves room for the center of learning or the individual teacher to make adaptations so that it makes better sense in the local context and for the individual learner.

\section{F. Joyful Learning in the School}

Learning in the schools in tribal areas must be joyful, meaningful and interesting, so that children will develop a desire to go to school. These may include sending students of primary level on a local tour to parks, historic sites, temples etc., using some techniques like theatre, music, song, dance, skit, puzzles etc. and promoting sports and games in the school. In tribal areas education must include culture friendly and child friendly materials like the folk stories, tribal dance and festivals, stories of successful tribal leaders, hunting techniques in the course curriculum to make learning enjoyable and to create interest among the tribal children for education. Every school in tribal area should include a period for local games. They must paste the photographs of the local tribal leaders along with national leaders in the school and adopt various joyful methods of teaching to enhance the attendance in the school.

\section{G. Assessment and Evaluation to Promote Inclusion}

Children's success in school is often believed to be primarily a function of their intellectual aptitudes. In case of learners who come from deprived environments, their living conditions may reduce their motivation and opportunities to learn, whatever their intellectual ability might be. Furthermore, the language of instruction may put children at a disadvantage, as discussed above. Learners who are unable to proceed with their classmates to the next grade may experience low self-esteem and are likely to develop negative attitudes towards education. Repeaters become then candidates for an eventual dropout.

An inclusive curriculum demands a flexible, successoriented means of assessment, examination and evaluation. The assessment of children is increasingly related to the aims of the curriculum, the culture and experience biography of the child and the way in which the curriculum is designed and delivered.

\section{H. Growing Consciousness}

While there is a lot, that the government needs to do to provide quality education to its tribal people, an equal responsibility rests with society to do its bit. Various civil societies must work practically to provide education to these backward communities. Apart from teaching community, every now and then - the politicians, bureaucrats, social workers, youth and others should take the responsibility to literate the needy. This growing social consciousness need to be promoted and sustained.

\section{Skill Development}

Skill development is a significant mechanism of a nation's 
knowledge initiative. There is a growing concern today that the education system is not fulfilling its role of building a bunch of skilled manpower, resulting in mismatch between the skill requirement of market and skill base of the employment seekers. As a result many educated people also suffer from unemployment. To address this problem we need to refurbish the system of vocational education and training especially in tribal areas of the country.

\section{J. Capacity Building Programs for Teachers}

There is a greater need to provide capacity building programmes to upgrade the professional skills of teachers. It can be done through providing motivational and leadership training to teachers. Vocational training programmes should be mandatory for teachers who are serving in tribal areas. As far as practicable the teachers should be trained in local tribal language or dialect to amplify intensive interaction with tribal students.

\section{K. Mobile School Facilities for out of School Children}

There are some children in tribal areas who cannot afford school education. Due to economic backwardness they forced to remain in home or go outside the home to earn certain livelihood. But they also need education for a better life. Mobile school facilities should be launched to provide education for these out of school tribal children. The training of these children should be fixed by considering their leisure hours.

\section{CONCLUSION}

The influence of broader political developments towards cultural diversity and more widespread democracy has reinforced the role of education in political socialization, and facilitating active democratic citizenship. As well as a great variety of individual talents, education has to face the wide range of cultural backgrounds of the groups making up society. Education has to take on the difficult task of turning diversity into a constructive contributory factor of mutual understanding between individuals and groups. Any educational policy must be able to meet the challenges of pluralism and enable everyone to find their place in the community to which they primarily belong and at the same time be given the means to open up to other communities. The International Commission on Education for the Twenty-First Century reminds that education policies must be sufficiently diversified and must be so designed as not to become another cause of social exclusion and that schools should foster the desire to live together [9].

With regards to pedagogy, curriculum, educational organization or financing inclusive education does not bring much additional on the educational agenda, but it analyses why education systems and educational programmes are not succeeding in providing education for all learners. It tries to bring together within a cohesive framework what is known about quality education in order to work towards systems that are more responsive to diversity. As a strategic approach, it identifies existing resources and innovative practices in local contexts, examines the barriers to learning, with a specific focus on groups vulnerable to marginalization and exclusion.

The barriers to learning in our country illustrated the complexity of the day-to-day realities which education systems have to take into account. There are no quick-fix solutions or cook book recipes as how to go about educational change. However, certain well directed policies and apposite scrutiny of the whole system can definitely facilitate the development of more inclusive education systems. Inclusion should be the guiding principle for the development work with Governments towards Education for All.

\section{REFERENCES}

[1] UNESCO, From Special Needs Education to Education for All, a Discussion Document, Tenth Steering Committee Meeting UNESCO Paris 30 September - 1 October 1998, unpublished manuscript, 1999.

[2] Dakar Framework for Action - Education for All, Meeting our Collective Commitment. [Online]. Available: http://www2.unesco.org/wef/en-conf/dakframeng.shtm

[3] UNESCO, The Salamanca World Conference on Special Needs Education: Access and Quality, UNESCO and the Ministry of Education, Paris, UNESCO, 1994.

[4] S. R. Padhi and B. Padhi, "Educational scenario of tribes in India," in Educational Scenario of Tribes in India: Current Issues and Concern, S. R. Padhi, Ed., New Delhi: Mangalam, 2011.

[5] Government of India, Eleventh Five Year Plan, New-Delhi, Planning Commission, 2007.

[6] Census, Government of India, New Delhi, Office of the Registrar General, India, 2011.

[7] J. Begi, "Education in Arunachal Pradesh since 1947: Constraints, opportunities, initiatives and needs," New-Delhi, Mittal, 2007

[8] UNESCO, Wasted Opportunities: When Schools Fail. Education for All, Status and Trends, Paris, UNESCO, 1998

[9] UNESCO, Learning: the Treasure Within, Report to UNESCO of the International Commission on Education for the Twenty-first Century, Paris: UNESCO, 1996

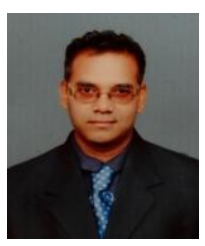

Soubhagya Ranjan Padhi was born on January 1, 1973 He has obtained his graduation degree in sociology 1991 from Ravenshaw College, Cuttack, post-graduation in sociology 1994 and M.Phil in sociology 1996 from Central University Hyderabad. He has qualified in national eligibility test (NET) and received junior research fellowship (JRF) conducted by UGC. He has completed his PhD degree in sociology 2010 from Fakir Mohan University, Orissa.

Dr. Padhi was working as a lecturer in sociology at Aeronautics College, Sunabeda, Odisha from 1999 to 2012 and currently working as an associate professor and head in the Department of Sociology at Rajiv Gandhi Central University, Arunachal Pradesh. Besides supervising research scholars, he has since long been engaged in the empirical socio-anthropological studies on various tribes of India. His interests and publications are in the field of tribal studies, sustainable development, community mobilization, social exclusion, rural livelihood and watershed management. 